\title{
Association Between Mannose Binding Lectin Level and Progression of Chronic Hepatitis B
}

\author{
Elife Erarslan $^{1 *}$, Barış Yılmaz ${ }^{1}$, Yusuf Coşkun ${ }^{1}$, Aydın Çifçìi ${ }^{2}$ Fuat Ekiz ${ }^{1}$, Zeynep Ginişs ${ }^{3}$, Şahin Çoban ${ }^{1}$ and İlhami Yüksel $^{1}$ \\ ${ }^{1}$ DışkapıYlldırımBeyazıt Training and Research Hospital, Department of Gastroenterology, Ankara, Turkey \\ ${ }^{2}$ Kirıkkale University Medical School, Department of Internal Medicine, Kirıkkale, Turkey \\ ${ }^{3}$ Dışkapı YildırımBeyazıt Training and Research Hospital, Department of Biochemistry, Ankara, Turkey
}

\begin{abstract}
Background: Mannose binding lectin (MBL) is believed to be an important component of the innate immune response. MBL may be an important non-invasive predictor for progression of hepatitis B virus infection. In this study, we examined whether there is a relationship between MBL levels and progression of hepatitis B virus infection.
\end{abstract}

Methods: In this cross-sectional study, fifty patients with chronic hepatitis B and 21healthy control subjects were included. They were classified into three groups: Active hepatitis B, inactive hepatitis B and healthy control groups. The association between MBL level with the stage of fibrosis and histological activity index (HAI) was found in patients with active chronic hepatitis B.

Results: The mean \pm SD of MBL level was as $2875.3 \pm 2040.03 \mathrm{ng} / \mathrm{ml}$ in active HBV patients, $2463.9 \pm$ $1915.4 \mathrm{ng} / \mathrm{ml}$ in inactive HBV patients, and $1865.04 \pm 265.6 \mathrm{ng} / \mathrm{ml}$ in healthy controls (P: 0.344). MBL was not significantly correlated with HAI and the stage of fibrosis (r: $-0.30, \mathrm{P}: 0.876$ and r: $0.077, \mathrm{P}: 0.687$, respectively).

Conclusion: In our study, we could not find any significant association between MBL levels and progression of HBV infection; which is not in line with the hypothesis that MBL may be beneficial as a non-invasive predictor of the survival of patients with hepatitis B virus infection.

\section{Introduction}

It is estimated that there are approximately 350-400 million hepatitis $\mathrm{B}$ virus (HBV) carriers and 240 million patients chronically infected with HBV in the world. The spectrum of HBV infection ranges from asymptomatic carriers, acute hepatitis, chronic hepatitis, fulminant liver deficiency, cirrhosis to hepatocellular carcinoma (HCC) [1-3]. Various factors including age at the onset of infection, sex, immune status, ethnic origin, alcohol intake and dual infection with other viruses which affect the liver (HIV, HCV) may have a role in the progression to chronic hepatitis $\mathrm{B}$ (CHB) [1,3]; however, the question of how HBV infection affects the liver is still not clear.

Serum mannose binding lectin (MBL) is an important molecule in human innate immunity [4]. This protein is a calcium-dependent lectin that acts directly as an opsonin by binding to collectin receptors through its collagen domain [4-7]. Serum MBL levelsvary from $<20$ $\mathrm{ng} / \mathrm{ml}$ to $10,000 \mathrm{ng} / \mathrm{ml}$ [8], but it can arise to twofold or threefold in cases with infections [7]. Serum MBL may have an influence on disease progression via regulating the production of inflammatory cytokines such as IL-6, IL-1ß, and TNF- $\alpha$ by monocytes as a result of infection [9]. Low MBL level may confer a generalized sensibility to infection in children and adults [10]. The MBL gene was reported to play a significant role in the progression of $\mathrm{HBV}$ infection in adulthood [11]. Heterogeneity of the MBL gene was informed to be a significant factor in the assessment of the prognosis in chronic hepatitis C [12]. Low serum MBL levels were associated with the occurrence of poor prognosis in progressed carriers [2,5], however, other studies do not confirm these findings [13]. In this study, we investigated the association between MLB level and chronic hepatitis B disease.

\section{Materials and Methods}

\section{Patients}

A total of 71 subjects (male: 35 [49.3\%], female: 36 [50.7\%]) was enrolled from the outpatient clinic of the Gastroenterology Department of DışkapıYıldırımBeyazıt Training and Research Hospital. The patients were classified into three groups; Group1; active chronic hepatitis [n: $30, \mathrm{HBsAg}(+)$, elevated transaminase $\geq$ 2 times the upper limit of normal at least once during the followup period]; Group 2; inactive chronic hepatitis [n:20, HBsAg (+), normal transaminase level, HBVDNA; negative]; Group 3; the healthy controls [n:21]. The diagnostic criteria for chronic HBV infection were; seropositivity for HBsAg more than 6 months and seronegativity for anti-HBs and presence of anti-HBc. Patients with chronic hepatitis and inactive carriers had no evidence of portal hypertension and/or liver cirrhosis and HCC. Stage of fibrosis is classified according to Ishak scoring system. The patients with chronic active hepatitis were divided into three groups according to the stage of fibrosis (Group 1F: stage 0,1; Group 2F: stage 2-3; Group 3F: stage 4-5. The study was approved by the Ethics Committee of DışkapıYıldırımBeyazıt Training and Research Hospital. Informed consent was obtained from all subjects.

"Corresponding Author: Dr. Elife Erarslan, DışkapıYıldırımBeyazıt Training and Research Hospital, Department of Gastroenterology, İrfan BaştuğCaddesi, ZIP code: 06110, Dışkapı/Ankara, Turkey; E-mail: elifeerarslan@gmail.com

Citation: Erarslan E, Yılmaz B, Coşkun Y, Çifçi A, Ekiz F, et al. (2017) Association Between Mannose Binding Lectin Level and Progression of Chronic Hepatitis B. Int J Gastroenterol Disord Ther 4: 132. doi: https://doi.org/10.15344/2393$8498 / 2017 / 132$

Copyright: (C) 2017 Erarslan et al. This is an open-access article distributed under the terms of the Creative Commons Attribution License, which permits unrestricted use, distribution, and reproduction in any medium, provided the original author and source are credited. 
Citation: Erarslan E, Yılmaz B, Coşkun Y, Çifçi A, Ekiz F, et al. (2017) Association Between Mannose Binding Lectin Level and Progression of Chronic Hepatitis B. Int J Gastroenterol Disord Ther 4: 132. doi: https://doi.org/10.15344/2393-8498/2017/132

Page 2 of 5

\section{Laboratory analysis}

Fasting blood samples were obtained to measure serum levels of alanine aminotransferase (ALT), aspartate aminotransferase (AST), prothrombin time (PT), partial prothrombin time (PPT), HBsAg, Anti $\mathrm{HBs}, \mathrm{HBeAg}$, antiHBe, anti-HBc and HBVDNA. Serum ALT and AST levels were determined by spectrophotometric assay (modified IFCC method, Advia 2400, Siemens Healthcare Diagnostics Inc., TarrytownUSA). Plasma PT (Thromborel S reagent) and PTT (Dade Actin FSL Activated PTT Reagent) were measured using an automated coagulation analyzer (Siemens Dade Behring BCS XP, Tarrytown USA). HBsAg and anti-HBs antibody, $\mathrm{HBeAg}$ and antiHBe antibody were measured using enzyme-linked immunosorbent assay (ELISA) (DiasorinEti-max 3000, Italy). AntiHBcIgM was determined by electrochemiluminescent assay (Roche Diagnostics GmbH, Mannheim, Germany). HBVDNA was measured using RealTime PCR (Qiagene, Valencia; CA).

\section{Serum mannose-binding lectin measurement}

Fasting venous blood samples were obtained from all subjects after an overnight fasting for the assessment of serum level of MBL and stored at $-80^{\circ} \mathrm{C}$ until analysis. MBL oligomer level was measured by commercial ELISA kit (Bioporto diagnostic, Denmark). Calibrators, samples, and controls were incubated in micro-wells precoated with monoclonal MBL antibody. MBL present in the solutions binds to the antibody-coated wells. Biotinylated monoclonal detection antibody was added to incubate. Unbound detection antibody was removed by washing. HRP-conjugated streptavidin was added to each test well-unbound conjugate was removed by washing. After TMB (tetramethylbenzidine) was added, the enzymatic reaction was stopped chemically. The absorbance was read at $450 \mathrm{~nm}$ in an ELISA reader (EPOCH, USA). The interassay coefficient of variation for level 1 was $3.6 \%$. The interassay coefficient of variation for level 2 was $3.8 \%$. The interassay coefficient of variation for level 1 was $9.2 \%$. The interassay coefficient of variation for level 2 was $4.3 \%$.

\section{Statistical analysis}

Differences in age, ALT, AST, HBV-DNA, HBeAg, platelet count and MBL levels between patients and controls were assessed by Kruskal-Wallis and Mann-Whitney U-test. Pearson's correlation test was used to determine the association between MBL, AST, ALT, HBeAg, HBV DNA and platelet count in active/inactive chronic hepatitis and controls. Pearson's correlation test was used to determine the association between MBL level, stage of fibrosis and HAI in active chronic hepatitis. All statistical analyses were performed using the SPSS program, version 17.0 [SPSS Inc, Chicago, IL, USA]. Statistical significance was accepted at $\mathrm{P}<0.05$.

\section{Results}

Clinical and viral backgrounds of patients in every three groups are depicted in Table 1 . The mean \pm SD of MBL level was as 2875.3 $\pm 2040.03 \mathrm{ng} / \mathrm{ml}$ in active HBV patients, $2463.9 \pm 1915.4 \mathrm{ng} / \mathrm{ml}$ in inactive HBV patients, and $1865.04 \pm 265.6 \mathrm{ng} / \mathrm{ml}$ in healthy controls $(\mathrm{p}=0.344)$. MBL levels were higher in active hepatitis B group than inactive hepatitis $\mathrm{B}$ and control group. But, the difference did not reach statistical significance (Figure 1). The correlation analysis did not show any significant association of MBL levels with the stage of fibrosis (r: 0.077, p: 0.687) (Figure 2). No correlation was observed between MBL and HAI and between MBL and stage of fibrosis ( $\mathrm{r}$ : $-0.30, \mathrm{P}: 0.876$ and r: $0.077, \mathrm{P}: 0.687$, respectively). Comparison of the baseline parameters in term of the stage of fibrosis is depicted in Table 2. Statistically, the significant difference was observed in age between group 1 fibrosis $(\mathrm{F})$ and group $2 \mathrm{~F}(\mathrm{P}=0.014)$. Serum ALT level and HBVDNA were significantly lower in group $1 \mathrm{~F}$ compared with group $2 \mathrm{~F}(\mathrm{P}=0.041)$ and significantly lower in group $1 \mathrm{~F}$ compared with group $3 \mathrm{~F}(\mathrm{P}=0.039$ and $\mathrm{P}=0.013$, respectively). Serum AST level was significantly lower in group $1 \mathrm{~F}$ compared with $2 \mathrm{~F}(\mathrm{P}=0.041)$ (Table 2).

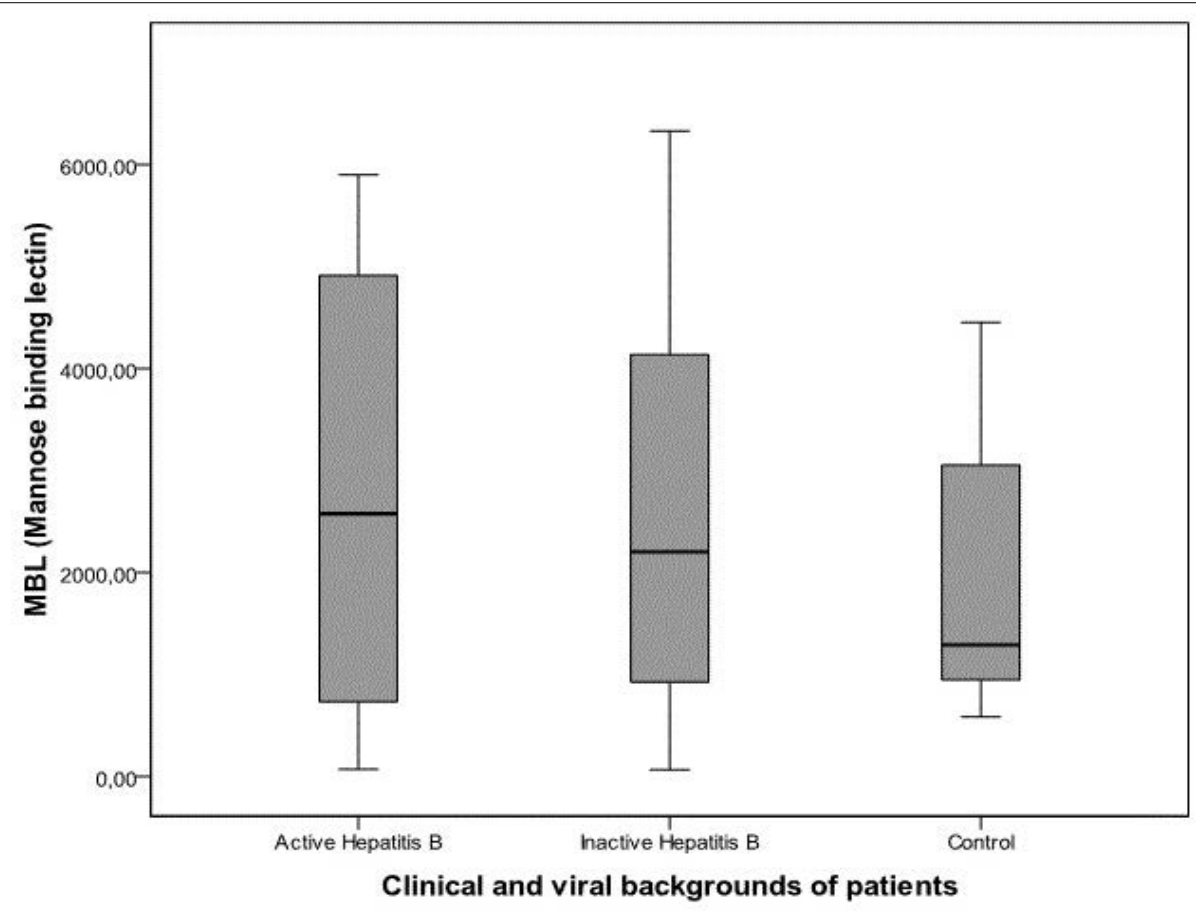

Figure 1: MBL levels (mannose binding lectin, $\mathrm{ng} / \mathrm{mL}$ ) were higher in active hepatitisB group than inactive hepatitis B and control group. But, the difference did not reachstatistically significance. 
Citation: Erarslan E, Yılmaz B, Coşkun Y, Çifçi A, Ekiz F, et al. (2017) Association Between Mannose Binding Lectin Level and Progression of Chronic Hepatitis B. Int J Gastroenterol Disord Ther 4: 132. doi: https://doi.org/10.15344/2393-8498/2017/132

Page 3 of 5

\begin{tabular}{|c|c|c|c|c|}
\hline Groups & Group 1 Active Hepatitis B (n:30) & Group 2 Inactive Hepatitis B (n:20) & Group 3 control (n:21) & $\mathrm{p}$ \\
\hline $\operatorname{Sex}(M: F)$ & $16 / 14$ & $8 / 12$ & $11 / 10$ & 0.621 \\
\hline Age, years old (mean $\pm S D)$ & $45 \pm 14.1$ & $41.8 \pm 10.9$ & $45.6 \pm 12.7$ & 0.50 \\
\hline Serum AST(IU/L), (mean \pm SD) & $61 \pm 55.5$ & $26.9 \pm 19.8$ & $22.6 \pm 8.8$ & $<0.001$ \\
\hline Serum ALT (IUL) $($ mean \pm SD) & $86.8 \pm 83.5$ & $31.5 \pm 29.8$ & $22.4 \pm 11.9$ & $<0.001$ \\
\hline Platelet $\left(\times 10^{3} / \mathrm{L}\right)$, (mean) & 177.500 & 211.250 & 240.750 & 0.002 \\
\hline HBeAg(negative), N(\%) & $26(86.7)$ & $20(100)$ & $21(100)$ & 0.058 \\
\hline HBV DNA titer, mean (IU/mL) & 1.471 .683 & 504.9 & 0.0 & $<0.001$ \\
\hline $\mathrm{MBl} \mathrm{ng} / \mathrm{ml},($ mean/SD) & $2857.3 \pm 2040.03$ & $2463.9 \pm 1915.4$ & $1865.04 \pm 265.6$ & 0.344 \\
\hline
\end{tabular}

Table 1. Clinical and Viral Backgrounds of Patients in Each Three Groups.

Abbreviations: AST, aspartate aminotransferase; ALT, alanine aminotransferase; MBL,Mannose binding lectin.

Note: Comparisons of continuous variables such as ALT, AST, platelet and HBV-DNA count among three groups were made by the Kruskal-Wallis

Test, and $\mathrm{P}<0.05$ was accepted assignificant.

\begin{tabular}{|c|c|c|c|c|}
\hline Groups & Group 1F, Stage $0-1$ & Group $2 \mathrm{~F}$, Stage 2 and 3 & Group 3 F Stage 4 and 5 & $\mathrm{p}$ \\
\hline $\operatorname{Sex}(M: F)$ & $5 / 7$ & $5 / 6$ & $6 / 1$ & 0.144 \\
\hline Age, years old (mean $\pm S D)$ & $39.8(8.5)$ & $45.5(14.3) \mathbf{g}$ & $55.7(16.0) \#$ & 0.014 \\
\hline Serum AST(IU/L), $($ mean \pm SD) & $10(83.3 \%)$ & $10(90.9 \%)$ & $6(85.7 \%)$ & 0.868 \\
\hline Serum ALT (IUL) $($ mean \pm SD) & $39.1 \pm 29.9$ & $82.7 \pm 78.3$ g & $58.0 \pm 17.6$ & 0.041 \\
\hline Platelet $\left(\times 10^{3} / \mathrm{L}\right),($ mean $)$ & $56.2 \pm 53.4^{*}$ & $126.4 \pm 113.19$ & $66.8 \pm 13.3$ & 0.039 \\
\hline HBeAg(negative), N(\%) & $197.363 \pm 24.700$ & $163.500 \pm 44.270$ & $170.285 \pm 33.700$ & 0.069 \\
\hline HBV DNA titer, mean (IU/mL) & $1.991 .000^{*}$ & $1.328 .000 \mathrm{~g}$ & 805.857 & 0.013 \\
\hline MBl ng/ml, (mean/SD) & $2927 \pm 1950.5$ & $2282 \pm 2304.3$ & $38.08 \pm 15.21 .7$ & 0.310 \\
\hline
\end{tabular}

Table 2. Comparison of The Baseline Parameters in Term of The Fibrosis Severity in Liver.

Note: $\mathrm{P}$ values revealed the results of Kruskal Wallis test which compared all of the three groups

overall, $\mathrm{P}<0.05$ was accepted as significant.

${ }^{*}$ gave the significant difference results revelaed by post hoc tests of Mann Whitney U test or Chisquaretest which compared the difference between

Group 1 and 3.

gave the significant difference results revelaed by post hoc tests of Mann Whitney U test or Chi-square test which compared the difference between

Group 1 and 2 .

\# gave the significant difference results revelaed by post hoc tests of Mann Whitney U test or Chi-square test which compared the difference between Group 2 and 3

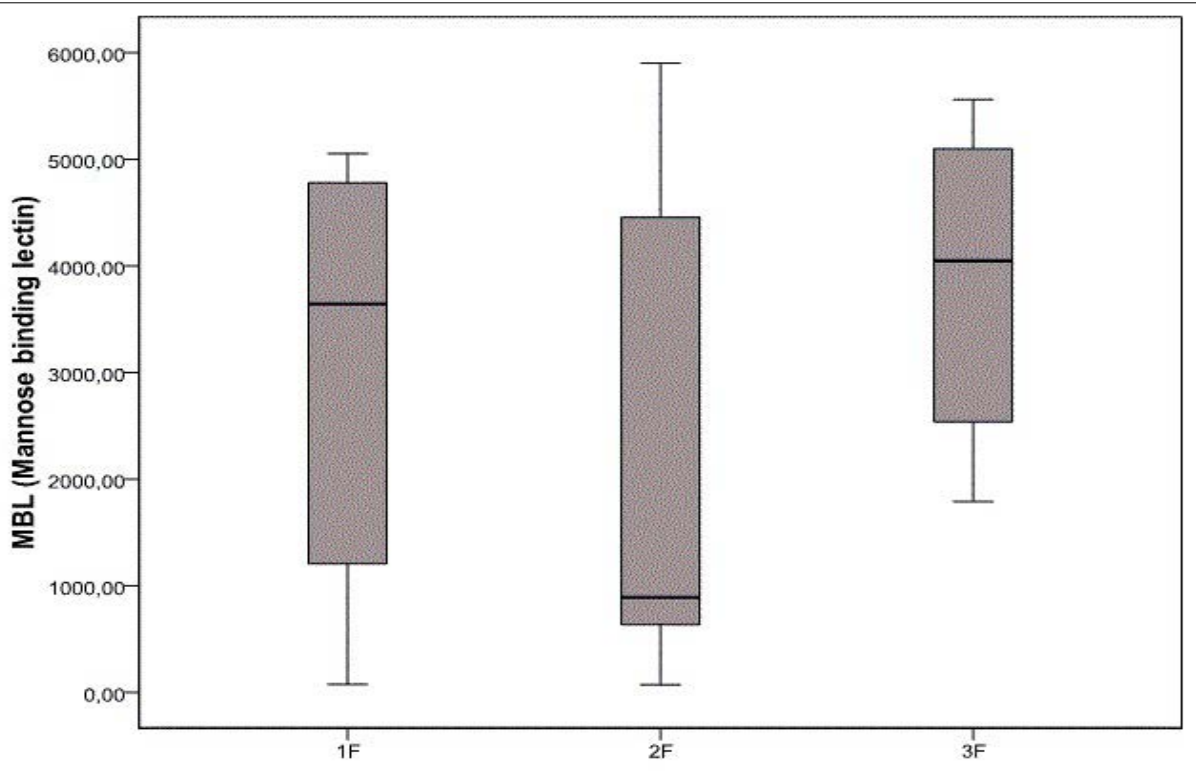

Fibrosis severity in liver

Figure 2: Comparison of serum MBL levels (mannose binding lectin, ng / $\mathrm{mL}$ ) and stage of fibrosis in patients with active hepatitis B. The correlation analysis did not show anysignificant association between MBL levels and stage of fibrosis (r: 0.077, P: 0.687). 
Citation: Erarslan E, Yılmaz B, Coşkun Y, Çifçi A, Ekiz F, et al. (2017) Association Between Mannose Binding Lectin Level and Progression of Chronic Hepatitis B. Int J Gastroenterol Disord Ther 4: 132. doi: https://doi.org/10.15344/2393-8498/2017/132

Page 4 of 5

\section{Discussion}

In this study, we examined the association between MBL levels with progression of chronic hepatitis B disease. Although MBL levels were higher in active hepatitis $B$ group than in patients with inactive hepatitis $\mathrm{B}$ and control group, the difference did not reach statistical significance. MBL was not correlated with HAI and the stages of fibrosis. One of the major public health problems in the world is persistent HBV infection. Numerous factors including viral and host factors may play a role in the pathogenesis of viral hepatitis. The pathogenesis of progression from chronic liver disease to cirrhosis is a multistage process involving chronic liver cell injury, inflammation, fibrosis and hepatocyte regeneration [14,15]. Increased inflammatory cytokines may contribute to fibrogenesis and proliferation of hepatocytes leading to cirrhosis and HCC [14,15]. The extent of liver fibrosis is significantly related to prognosis and management of chronic viral hepatitis [16]. There are numerous non-invasive methods for the assessment of liver fibrosis which are fibroscore, AST/ ALT ratio (AAR), AST-to-platelet ratio index (APRI), sonography, Fibro- $a$ score, King score, Biotechnology Research Center scores and transient elastography [17].

The MBL gene was reported to play an important role in determining the progression of HBV infection. MBL is known to be an acute phase reactant, rising up to threefold after infection or surgery [2,4-7,13]. The human MBL gene (mbl2) is located on chromosome 10q11.1-q21 [18]. The patients' immune response which may partly depend on gene mutations of MBL is associated with the clinical result of HBV infection $[19,20]$. Homann et al. reported an increased serum MBL level in patients with decompensated alcoholic cirrhosis [21]. Hakozaki et al. studied serum MBL levels in 43 patients with fulminant hepatic failure (FHF) and 260 healthy controls and showed that high levels of serum MBL correlated with the survival of patients with FHF due to HBV infection. Therefore, they concluded that serum MBL may be useful as a predictive factor for the survival of patients with FHF caused by HBV [2]. Comparable results were shown in our study revealing higher MBL levels inactive HBV group than inactive HBV group. But, the difference did not reach statistical significance. In another study, Chong et.al reported lower MBL levels in progressed HBV carriers when compared with nonprogressed carriers. Also in this study, they showed that low MBL genotype was associated with the occurrence of cirrhosis and HCC in progressed HBsAg carriers [5]. Another study examined MBL2 polymorphisms in Chinese subjects classified as asymptomatic chronic (n: 64), cirrhotic (n: 45) and HCC (n: 37). They found that median MBL levels were lower in all groups than the control group but there was no difference in MBL levels between disease groups [20]. Various studies examined the potential effect of MBL polymorphisms in HBV disease; some studies find a relation between MBL polymorphisms that present low levels of protein and poor prognoses such as viral persistence [22], disease progression [5,20,23], HBV progression [23] and survival of fulminant hepatic failure [2]. Thio et al. found that MBL2 genotypes correlating with increased MBL levels are related to recovery from an HBV infection whereas those correlating with lower levels are associated with viral persistence [22]. In conclusion; the association between MBL levels and the progression of HBV infection is still not clear and this relation has not been studied in Turkish population previously. MBL may be beneficial as a noninvasive predictor of the survival of patients with hepatitis B virus infection. Therefore, we examined whether there was a relationship between MBL levels with progression of hepatitis B virus infection using liver fibrosis. However, we could not find any significant association between MBL levels and progress of HBV infection in our patients. Further prospective studies on large patient populations are needed to examine whether there was a clear relationship between MBL and progression of hepatitis B virus infection.

\section{Competing Interests}

The authors have declared that no competing interest exists.

\section{References}

1. McMahon BJ (2004) The natural history of chronic hepatitis B virus infection. Semin Liver Dis 24: 17-21.

2. Hakozaki Y, Yoshiba M, Sekiyama K, Seike E, Iwamoto J, et al. (2002) Mannose-binding lectin and the prognosisof fulminant hepatic failure caused by HBV infection. Liver 22: 29-34.

3. Hadziyannis SJ, Papatheodoridis GV (2006) Hepatitis Be antigen negative chronic hepatitis B- natural history and treatment. Semin Liver Dis 26: 130 141.

4. Matsushita M, Fujita T (1992) Activation of the classical complement pathway by mannosebinding protein with a novel Cls-like protease. J Exp Med 176: 1497-1502.

5. Chong WP, To YF, Ip WK, Yuen MF, Poon TP, et al. (2005) Mannose-binding lectin in chronic hepatitis B virusinfection. Hepatology 42: 1037-1045.

6. Malhotra R, Laursen SB, Willisac, Sim RB (1993) Localization of the receptor binding sitein the collectin family of proteins. Biochem J 293: 1519

7. Valdimarsson H, Vikingsdottir T, Bang P, Saevarsdottir S, Gudjonsson JE, et al. (2004) Human plasma-derived mannosebindinglectin: a phase I safety and pharmacokinetic study. Scand J Immunol 59: 97-102.

8. Steffensen R, Thiel S, Varming K, Jersild C, Jensenius JC (2000) Detection of structural genemutations and promoter polymorphisms in the mannanbinding lectin (MBL) gene bypolymerase chain reaction with sequencespecific primers. J Immunol Methods 241: 33-42.

9. Jack DL, Read RC, Tenner AJ, Frosch M, Turner MW, et al. (2001) Mannose-bindinglectin regulates the inflammatory response of human professional phagocytes to Neisseriameningitidis serogroup B. J Infect Dis 184: $1152-1162$.

10. Summerfield JA, Ryder S, Sumiya M, Thursz M, Gorchein A et al. (1995) Mannose binding protein gene mutationsassociated with unusual and severe infections in adults. Lancet 345: 886-889.

11. Thursz MR, Kwiatkowski D, Allsopp CE, Greenwood BM, Thomas HC, et al. (1995) Association between an MHC class II allele and clearance of hepatitis B virus inGambia. N Engl J Med 332: 1065-1069.

12. Sasaki K, Tsutsumi A, Wakamiya N, Ohtani K, Suzuki Y, et al. (2000) Mannose-binding lectin polymorphismsin patients with hepatitis $C$ virus infection. Scand J Gastroenterol 9: 960-965.

13. Cheong JY, Cho SW, Lim SK, Shin DH, Yoon SK, et al. (2005) Lack of association between hepatitis $B$ virusinfection and polymorphism of mannose-binding lectin gene in Korean population. J Korean Med Sci 20: 65-69.

14. Block TM, Mehta AS, Fimmel CJ, Jordan R (2003) Molecular viral oncology ofhepatocellular carcinoma. Oncogene 22: 5093-5107.

15. Kershenobich Stalnikowitz D, Weissbrod AB (2003) Liver fibrosis and inflammation: areview. Ann Hepatol 2: 159-163.

16. Ashraf S, Ahmed SA, Ahmed J, Ali N (2012) FibroScore for the non-invasive assessment of liver fibrosis in chronic viral hepatitis. J Coll Physicians Surg Pak 22: 84-90

17. Attallah AM, El-Far M, Omran MM, Farid K, Albannan MS, et al. (2013) Noninvasive diagnosis of liver fibrosis and cirrhosis in chronic hepatitis $\mathrm{C}$ patients. J Clin Lab Anal 27: 121-129.

18. Bernig T, Taylor JG, Foster CB, Staats B, Yeager M, et al. (2004) Sequence analysisof the mannose-binding lectin (MBL2) gene reveals a high degree of heterozygosity withevidence of selection. Genes Immun 5: 461-476. 
Citation: Erarslan E, Yılmaz B, Coşkun Y, Çifçi A, Ekiz F, et al. (2017) Association Between Mannose Binding Lectin Level and Progression of Chronic Hepatitis B. Int J Gastroenterol Disord Ther 4: 132. doi: https://doi.org/10.15344/2393-8498/2017/132

Page 5 of 5

19. Yuen MF, Lau CS, Lau YL, Wong WM, Cheng CC, et al. (1999) Mannose binding lectin gene mutations are associated with progression of liver disease in chronic hepatitis B infection. J Hepatology 29: 1248-1251.

20. Homann C, Garred P, Hasselqvist P, Graudal N, Thiel S, et al. (1995) Mannanbinding protein and complement dependent opsonization in alcoholic cirrhosis. Liver 15: 39-44.

21. Thio CL, Mosbruger T, Astemborski J, Greer S, Kirk GD, et al. (2005) Mannose binding lectin genotypesinfluence recovery from hepatitis Bvirus infection. J Virol 79: 9192-9196.

22. Song le H, Binh VQ, Duy DN, Jüliger S, Bock TC, et al. (2003) Mannose binding lectin gene polymorphisms andhepatitis $B$ virus infection in Vietnamese patients. Mutat Res 522: 119-125. 